\title{
Does Energy Poverty Affect Energy Efficiency Investment Decisions? First Evidence from a Stated Choice Experiment
}

\author{
Dimitris Damigos*(D), Christina Kaliampakou, Anastasios Balaskas $(\mathbb{D}$ and Lefkothea Papada \\ Lab of Mining and Environmental Technology, Zografou Campus, School of Mining and Metallurgical \\ Engineering, National Technical University of Athens, 15780 Athens, Greece; christinak.ck95@gmail.com (C.K.); \\ balaskas@metal.ntua.gr (A.B.); lefkipap@metal.ntua.gr (L.P.) \\ * Correspondence: damigos@metal.ntua.gr; Tel.: +30-2107722214
}

Citation: Damigos, D.; Kaliampakou, C.; Balaskas, A.; Papada, L. Does Energy Poverty Affect Energy Efficiency Investment Decisions? First Evidence from a Stated Choice Experiment. Energies 2021, 14, 1698. https://doi.org/10.3390/en14061698

Academic Editor: David Borge-Diez

Received: 18 February 2021

Accepted: 16 March 2021

Published: 18 March 2021

Publisher's Note: MDPI stays neutral with regard to jurisdictional claims in published maps and institutional affiliations.

Copyright: (c) 2021 by the authors. Licensee MDPI, Basel, Switzerland. This article is an open access article distributed under the terms and conditions of the Creative Commons Attribution (CC BY) license (https:// creativecommons.org/licenses/by/ $4.0 /)$.
Abstract: Energy poverty is a multidimensional and continuously growing societal problem, with political roots. In pursuit of mitigating the problem, the European Commission has adopted a bundle of policies, such as consumer protection measures, short-term financial interventions, motivations for energy efficiency (e.g., energy retrofits and replacement of old household appliance) and information campaigns, among others. There is no doubt, however, that increasing the income of vulnerable households would be the most preferred and effective option. Focusing on energy efficiency, a measure typically incorporated in the National Energy and Climate Plans (NECPs) of many Member States as a means to fight energy poverty, this paper aims to shed light on the need to gradually move towards more localized-not to say personalized-actions. In this direction, a labeled choicebased experiment is used, which involves a hypothetical selection between three alternative energy interventions, i.e., house retrofit, upgrading of heating system and upgrading of household electrical appliances. The research aims to integrate the preferences of households from the choice experiment with indicators of energy poverty and establish a connection between energy poverty and energy efficiency investment decisions. The results demonstrate that households' preferences are affected by qualitative and quantitative aspects of energy vulnerability and sociodemographic characteristics. Furthermore, vulnerable households seem to be more prone to the so-called "discounting gap", as previous studies also suggest. These findings are worrisome because, without tailor-made support, these households may never escape the vicious circle of energy poverty. To this end, the survey could provide useful information to policy-makers towards developing more robust policies of energy poverty alleviation.

Keywords: choice experiment; energy poverty; energy efficiency; willingness to pay

\section{Introduction}

Energy poverty is a major and continuously growing societal problem in Europe. According to the third pan-EU energy poverty report of the EU Energy Poverty Observatory (EU EPOV) [1], around 34 million people (almost 7.5\%) across EU-28 were unable to pay their utility bills in 2018, and more than 37 million people (8.2\%) experienced cold homes. Further, more than 82 million people (more than 18\%) spent a high share of their income on energy expenditure and might have had to cut back on other essential spending. On the other hand, more than 74 million people $(16.5 \%)$ had abnormally low energy expenditure due to unaffordability, which is sometimes referred to as hidden energy poverty. The problem is more acute in Eastern, Central and Southern Europe [2,3]. For instance, in 2018, Cyprus and Portugal had the fourth and fifth highest rates of inability to maintain houses adequately warm during the winter $(21.9 \%$ and $19.4 \%$, respectively) [1]. Energy poverty is strongly associated with poor health and poor wellbeing. To wit, Thomson et al. [2] find a higher incidence of poor health (both physical and mental) amongst the energy-poor populations. Oliveras et al. [3] report a statistically significant association, which is affected 
by gender, region and year of study, between three health outcomes (i.e., self-reported health status, WHO well-being index and likely depression) and the inability to keep home adequately warm. The latter is a common finding in several studies, showing that energy poverty is not equally distributed geographically and socially.

Energy poverty is acknowledged to be the result of low incomes, poor thermal efficiency of housing, poor energy efficiency of heating and cooling systems and appliances, and high energy prices. Overall, there are several factors involved. Papada et al. [4] attempted to give a holistic picture of the EP "system", focusing on Greece, combining the most decisive micro- and macro-drivers and the ways these drivers interact with one another. At a macrolevel, energy poverty is affected by drivers relating to energy requirements and climatic conditions, degree of urbanization, broader socioeconomic characteristics (e.g., sociopolitical system, physical and built environment and local services), and socio-spatial vulnerability variables (e.g., access, flexibility, affordability and needs) [5-9]. At a microlevel, housing conditions (e.g., dwelling type and type of heating systems used, building size and energy efficiency) and demographic characteristics (e.g., size of household, employment status, education, nationality, gender) $[6,10]$ are key factors. For instance, elderly, single parent families, households with people with disabilities or long-term illnesses, unemployed people and people in poorly paid jobs are more vulnerable to energy poverty [11,12].

In pursuit of mitigating the problem, the European Commission adopted and continues to develop policies and measures based on multiple disciplines, i.e., directives, funds and other initiatives (e.g., the EU EPOV) [13]. Most research and actions are ad hoc and carried out nationally instead of EU-wide [14]. Consumer protection measures and shortterm financial interventions-starting from the Directives 2003/54/EC and 2003/55/EC mentioning that actions needed to be taken to protect citizens against electricity disconnection and inability of bill payment-provide a relief to vulnerable consumers but do not help them escape energy poverty in the long term. Thus, the problem is also related to alternative matters, e.g., energy efficiency in buildings, market regulation for gas and electricity [13], events and general training (e.g., consultation centers), education and awareness (e.g., textbooks for schools) [15]. For example, energy poverty is mentioned in the Energy Efficiency Directive (2018/2002), the Energy Performance in Buildings Directive (2018/844) and the Governance Regulation (2018/1999) [16]. Information provision, in particular, is considered a low-cost strategy for triggering a change in consumer behavior and energy usage. As such, it could reduce energy consumption even by $20 \%$ [17], without additional costs for the energy vulnerable households. The Energy Efficiency Directive 2012/27 and the amending Directive 2018/2002 include specific provisions regarding consumer information and training.

Focusing on energy saving, the EU highlights the need to mobilize at least 100 billion Euros per year in this direction, although this is not something easy to implement [18]. Energy efficiency improvements, such as insulation of exterior walls and roof, installation of more energy-efficient doors and windows, upgrading of heating and cooling systems, replacement of analog thermostats with programmable ones, replacement of low energy class devices with energy-efficient ones, installation of solar water heaters etc., can significantly reduce energy consumption and lead to savings on households' energy costs. There are, however, two critical factors acting as barriers to energy-saving measures. First, many measures require high initial investments which are not affordable to vulnerable consumers. Second, on several occasions, consumers refrain from investing in energy efficiency even when they have the financial ability to do so and it makes economic sense, i.e., private benefits exceed private costs. The latter phenomenon is known in the literature as the "energy efficiency gap" or "energy paradox" $[19,20]$. The results of three decades of research have established that the energy paradox is related to market failures (e.g., imperfect information, split incentives, distortion in fuel prices and lack of capital), time and risk preferences, behavioral aspects (e.g., rational inattention, bounded rationality, biased beliefs and heuristic decision-making) and sociodemographic characteristics [20-30]. 
The abovementioned issues acquire even greater importance in the case of vulnerable consumers. This is not only because vulnerable consumers must reduce their energy consumption but also because scarcity affects people's cognitive functioning, changes how they allocate attention and may prevent them from making optimal decisions [30-32]. So far, several studies have shed light on the role of poverty (or poverty-related psychological and attitudinal short-fallings) on decision-making processes, e.g., [32-37]. In addition, some studies draw attention specifically to the effectiveness of energy efficiency interventions for vulnerable consumers from a behavioral perspective, e.g., [38,39], or the energy behavior as an additional driver of energy poverty $[30,40]$.

Our study aims to add to this body of knowledge by investigating the interrelationships between energy poverty and energy efficiency investment decisions. The study is based on a questionnaire survey carried out between November 2020 and January 2021 in Metsovo, a Greek mountain village of about 2500 people with 890 households, on a sample of 303 households. Regarding climatic characteristics, the mountain mass of Northern Pindos, where Metsovo is situated, contributes to the formation of particular climatic characteristics. The area is characterized by harsh weather conditions, low temperatures and high rainfall levels. The average annual temperature of the last 10 years ranges between 9.2 and $10.2^{\circ} \mathrm{C}$, the corresponding average annual maximum temperature ranges between 13.5 and $14.5^{\circ} \mathrm{C}$ and the average annual minimum temperature between 5.5 and $6.5^{\circ} \mathrm{C}$. The heating degree-days of Metsovo are significantly high and range between 2275 and $3194{ }^{\circ} \mathrm{C}$ * days, a fact that implies the great thermal energy needs of the buildings in the area.

In particular, the survey uses a labeled choice-based experiment, which involves a hypothetical selection between three different alternative energy interventions, i.e., house retrofit, upgrading of heating system and upgrading of household electrical appliances. In addition, it employs a series of questions to investigate dimensions of energy poverty. Using this experimental design, the aim of the survey is to analyze the preferences of households with respect to energy poverty vulnerability. To the authors' best knowledge, this is the first study of the field that integrates a choice experiment of consumer-stated preferences with energy poverty. In this direction, it is hoped that it will contribute to energy poverty reduction by providing useful findings to policy-makers.

The rest of the paper is organized as follows. Section 2 describes the methodological approach, i.e., the design of the survey and the specification of the econometric models used to analyze the data. Section 3 presents the results of the survey. Finally, Section 4 summarizes the main findings of the survey, provides directions for policy-makers and suggests a direction for future research.

\section{Experimental Design}

\subsection{Survey Design}

Towards collecting the necessary information for the survey, a stated preference approach was used based on personal interviews. The survey was conducted in the context of the "STEP-IN-Using Living Labs to roll out Sustainable Strategies for Energy Poor Individuals" project, which is funded from the EU's Horizon 2020 research and innovation programme and, therefore, the study area was the mountain village of Metsovo where one of the three Living Labs of the project had been established. In particular, more than 300 households participated in the survey through online platform interviews due to the COVID-19 pandemic-related distancing measures.

The core of the questionnaire consisted of a choice experiment where the respondents were presented with a number of choice sets and asked to choose which alternative they prefer. Each choice set included three alternatives, i.e., house retrofit, upgrading of heating system and upgrading of household electrical appliances, and an "opt-out" option (i.e., status quo). The respondents were asked to consider a hypothetical situation according to which their energy consumption would be improved by adopting one of the three alternative interventions. Each alternative, besides its label, was described using two 
parameters, i.e., the cost of the alternative and the annual energy savings in monetary terms. In order to provide the respondents with realistic attribute levels, each of the two attributes included three different levels that differed in each of the three alternatives. The attributes and the related levels for each of the three alternatives are listed in Table 1. It was assumed that the respondents assess the trade-off between the annual savings and the cost of each intervention. Further, they also consider additional co-benefits (or costs) associated with each alternative, such as improved thermal comfort, reduced condensation, mold or damp problems and increased environmental benefits due to reduction in primary energy.

Table 1. Levels of the attributes for each of the three labeled alternatives.

\begin{tabular}{cccc}
\hline & House Retrofit & $\begin{array}{c}\text { Upgrading of } \\
\text { Heating System }\end{array}$ & $\begin{array}{c}\text { Upgrading of Electrical } \\
\text { Appliances }\end{array}$ \\
\hline Cost of measure & 3000 Euros & 600 Euros & 300 Euros \\
(Euros) & 6000 Euros & 1200 Euros & 600 Euros \\
& 9000 Euros & 1800 Euros & 900 Euros \\
Annual savings & 500 Euros & 100 Euros & 50 Euros \\
(Euros) & 1000 Euros & 200 Euros & 100 Euros \\
& 1500 Euros & 300 Euros & 150 Euros \\
\hline
\end{tabular}

The full enumeration of possible choice sets is equal to $\mathrm{L}^{\mathrm{MA}}$, where $\mathrm{L}$ is the number of levels, $\mathrm{M}$ is the number of alternatives and $\mathrm{A}$ the number of attributes [41]. Hence, in our case, the total possible choice sets are $3^{3 \times 2}=729$. The experimental design followed Street and Burgess's cyclical design [42] using an orthogonal main-effects plan (OMEP) $3^{\wedge} 66^{\wedge} 1$. After dropping the unnecessary attributes, the design resulted in 18 treatment combinations. These 18 choice sets, which included an "opt-out" option, were split into three blocks of six choice cards to avoid respondent fatigue. Respondents were allocated randomly to a treatment block; making sure, however, that each of the three blocks was presented to an equal number of respondents.

Besides the choice experiment, the questionnaire included a number of questions relating to energy poverty. More specifically, the respondents were faced with the three questions of the pan-European Survey on Income and Living Conditions (EU-SILC), i.e., whether the household is able to keep the home warm during winter days, whether the household has had arrears in its utility bills, whether the house has leakages or damp walls etc. The responses in these questions were taken into account to calculate the composite energy poverty index, as follows [43]:

Energy poverty index $=(0.5 \times$ Inability $+0.25 \times$ Arrears $+0.25 \times$ Housing faults $) \times 100$

In addition, the respondents were asked to provide an estimate of their annual energy expenditure.

The third and fourth parts of the questionnaire presented a series of statements aiming to explore certain informative, market and behavioral barriers to energy efficiency and the impact of the COVID-related restriction measures on households' energy consumption. Nevertheless, these issues are not further discussed in this paper. The fifth and last part of the questionnaire investigated typical sociodemographic and housing characteristics of the participants.

\subsection{Statistical Analysis and Model Specification}

In choice experiments, the utility of a good or service derives from the consumer's theory of value [44]. Assuming a utility-maximization decision context, consumers maximize their utility by weighting the competing characteristics of the alternative choices (e.g., annual energy savings versus price in this case). According to the random utility theory, the utility of the good is considered to depend on observed components (the at- 
tributes of the good and the characteristics of the respondent) and unobserved or undefined component, as follows [41]:

$$
U_{i j}=V_{i j}+\varepsilon_{i j}=\beta X_{i j}+\gamma Z_{i}+\varepsilon_{i j}
$$

where $U_{i j}$ is the utility function representing the satisfaction that consumer $i$ receives from alternative $j ; V_{i j}$ is the non-stochastic component including the alternative-specific attributes $X_{i j}$ and the respondent's characteristics $Z_{i j} ; \beta$ and $\gamma$ are the vectors of models parameters associated with $X_{i j}$ and $Z_{i j}$; and $\varepsilon_{i j}$ is the unobserved (stochastic) component of consumer $i$, which follows a predetermined distribution.

The probability that consumer $i$ chooses alternative $j$ from any other alternative $k$ from a choice set $C_{i}$ is given by:

$$
\begin{aligned}
& P_{\left(j \mid C_{i}\right)}=\operatorname{Prob}\left(U_{i j}>U_{i k} ; j \neq k, \forall k \in C_{i}\right) \\
\Rightarrow & \operatorname{Prob}\left(V_{i j}+\varepsilon_{i j}>V_{i k}+\varepsilon_{i k} ; j \neq k, \forall k \in C_{i}\right) \\
\Rightarrow & \operatorname{Prob}\left(V_{i j}-V_{i k}>\varepsilon_{i j}-\varepsilon_{i k} ; j \neq k, \forall k \in C_{i}\right)
\end{aligned}
$$

Assuming a linear relationship between utility and attributes, identically and independently distributed (IID) error terms with standard Type I extreme value distribution and choice sets that comply with the "Independence from Irrelevant Alternatives" (IIA) property [45], the model above can be estimated with a conditional logit (CL) model [41]:

$$
P_{i j}=\frac{\exp \left(\mathrm{V}_{i j}\right)}{\sum_{k=1}^{C} V_{i k}}
$$

According to (4), the probability of an individual $i$ choosing alternative $j$ out of the set of $C$ alternatives is equal to the ratio of the exponential of the observed utility for alternative $j$ to the sum of the exponentials of the observed utility for all alternatives in $C$.

The model may also include an alternative-specific constant (ASC), which represents on average the role of all the unobserved sources of utility and shows the diversity in preference for the alternatives [41].

The model offers the ability to estimate the marginal willingness-to-pay (MWTP) for 1 Euro of additional annual savings. This is defined as the marginal rate of substitution between the annual savings and the cost of intervention that is the energy savings coefficient divided by the cost coefficient:

$$
M W T P_{\text {sav }}=-\frac{\beta_{\text {sav }}}{\beta_{\text {cost }}}
$$

In order to estimate the confidence intervals around the MWTP, the Krinsky-Robb approach was used [46], which involves multiple random drawings (in this case 1000 draws were made) of the $\beta$ coefficients from the asymptotic normal distribution of the estimator, with mean $\beta$ and variance-covariance matrix $V(\beta)$ [47].

In the case of an interaction term with the annual savings attribute, the MWTP is calculated, as follows [48]:

$$
M W T P_{\text {sav_interact }}=-\frac{\beta_{\text {sav }}+\beta_{\text {savxinteract }} \text { Savings } \times \text { Interacted term }}{\beta_{\text {cost }}}
$$

Finally, a respondent's WTP for a change from the base case (status quo, $U_{0}$ ) to a new state (energy intervention, $\left.U_{1}\right)$ is estimated through the compensating variation $(\mathrm{CV})$ associated with this change [48]:

$$
C V=-\frac{1}{\beta_{\text {cost }}} \times\left\{V_{1}-V_{0}\right\}
$$


The analysis was conducted using CL models. The basic model included three attributes (i.e., alternative specific constant, annual savings and cost of measure), which were specific to each alternative (that is, nine variables in total). It is noted that the cost and annual savings were modeled as continuous variables. More specifically, the utility functions of the basic model were as follows:

$$
\begin{gathered}
U_{\text {insulation }}=\beta_{01} \times A S C+\beta_{11} \times \text { Cost of measure }+\beta_{21} \times \text { Annual savings }+\varepsilon_{i j} \\
U_{\text {heating }}=\beta_{02} \times A S C+\beta_{12} \times \text { Cost of measure }+\beta_{22} \times \text { Annual savings }+\varepsilon_{i j} \\
U_{\text {appliances }}=\beta_{03} \times A S C+\beta_{13} \times \text { Cost of measure }+\beta_{23} \times \text { Annual savings }+\varepsilon_{i j}
\end{gathered}
$$

In addition, a fourth utility function that represented the status quo situation was used as the base case scenario. The parameters of the base case utility function were normalized to zero (i.e., $U_{0}=0$ ).

In order to investigate the role of respondents' sociodemographic characteristics (SDCs) for investing in energy efficiency, a number of SDC variables were included in the basic model. In these models, the SDC parameters were generic (i.e., the coefficients were not alternative-specific). In addition, three different models were initially considered to dissect the role of energy poverty. The first model involved the introduction of the composite energy poverty index in the basic model as a nonalternative-specific covariate. In the second model, the composite energy poverty index was replaced by the three subjective energy poverty indicators, again as generic covariates. The third model included the same three subjective energy poverty indicators, which were modeled as alternativespecific covariates in this case to gain a better understanding of if and how these poverty indicators influence differently the three alternative energy efficiency interventions.

\section{Results}

\subsection{Sociodemographic Statistics}

The main housing and socioeconomic characteristics of the survey sample are presented in Table 2.

As mentioned, a total number of 303 households participated in the survey, most of which, i.e., $59.3 \%$, include three or more persons, $24.5 \%$ include two persons and $12.6 \%$ consist of single-person households. The share of the elderly people (i.e., over 65 years old) is $21.2 \%$. In addition, $66 \%$ of the population is aged between 31 and 65 years old (i.e., $25.9 \%$ between 31 and 45 years old and $40.1 \%$ between 46 and 65 years old) and the rest are between 18 and 30 years. About 15\% have not reached high school, 26\% have stopped their education at the end of senior high school, $14.5 \%$ have finished a 2-year vocational degree, $37 \%$ have a three-, four- or five-year degree and about $10 \%$ have an MSc or a PhD degree. Concerning employment status, $64.4 \%$ are employed $(31.9 \%$ are full-time and $32.5 \%$ are part-time employees) and $32.5 \%$ are retired. Finally, more than half of the participants are managing to make ends meet on their income $(85 \%$ of the respondents in this category declare income between 750 and 1750 Euros per month), 15.5\% live comfortably (88\% of the respondents in this category declare income above 1750 Euros per month) but $9.4 \%$ are struggling to cope with current income ( $85 \%$ of the respondents in this category declare income less than 1050 Euros per month).

About $60 \%$ of the dwellings were constructed before 1980, the year that the first Greek Thermal Regulation was implemented. One-third of them were built after 1980 and before 2000 and the rest after 2000. About one-third of the residences are less than $80 \mathrm{~m}^{2}$, one-third between 80 and $100 \mathrm{~m}^{2}, 22 \%$ between 100 and $120 \mathrm{~m}^{2}$ and the rest are over $120 \mathrm{~m}^{2}$. Nearly $6 \%$ have two rooms, $13 \%$ have three rooms, $60.9 \%$ have four to five rooms and the rest have more than five rooms, except for bathrooms and storage rooms.

Among the households that took part in the survey, the dominant fuels are heating oil and biomass, namely firewood and pellets (these two fuels account for about $95 \%$ of the local households). In detail, $43 \%$ of the households use oil-fired central heating systems, 34\% use firewood and pellets central heating systems, 18\% use wood or pelletfired stoves, and the rest of the households use other systems (e.g., air-conditioning units, 
heat accumulators and fireplaces). The average annual energy cost for heating is slightly over 2000 Euros and that of electricity around 900 Euros. The heating cost varies according to the fuel used. More specifically, the annual heating cost is around 2500 Euros for the oil-fired heating systems, 1800 Euros for the firewood and pellets central heating systems and 1400 Euros for the wood or pellet-fired stoves.

Table 2. Population and housing characteristics.

\begin{tabular}{|c|c|c|c|}
\hline Demographics & Percent & Housing Characteristics & Percent \\
\hline Sex & & Built year of property & \\
\hline Female & 35.0 & Before 1920 & 3.3 \\
\hline Male & 65.0 & Between 1920 and 1940 & 4.0 \\
\hline Age & & Between 1941 and 1960 & 10.9 \\
\hline Less than 30 & 12.8 & Between 1961 and 1980 & 39.9 \\
\hline Between 31 and 45 & 25.9 & Between 1981 and 1990 & 21.8 \\
\hline Between 46 and 60 & 33.3 & Between 1991 and 2000 & 13.2 \\
\hline Between 61 and 75 & 20.5 & Between 2001 and 2010 & 5.6 \\
\hline More than 75 & 7.4 & After 2010 & 1.3 \\
\hline Marital status & & Size of property & \\
\hline Single (never married) & 23.8 & Less than 60 sq. $\mathrm{m}$ & 3.0 \\
\hline $\begin{array}{l}\text { Married, or in domestic } \\
\text { partnership }\end{array}$ & 62.6 & Between 61 and 80 sq. m & 27.3 \\
\hline Divorced & 2.6 & Between 81 and 100 sq. m & 35.0 \\
\hline Separated & 0.3 & Between 101 and 120 sq. m & 21.7 \\
\hline Living with a friend or relative & 1.7 & Between 121 and 140 sq. m & 7.3 \\
\hline Widowed & 8.6 & More than 140 sq. m & 5.7 \\
\hline I prefer not to answer & 0.4 & Primary heating system & \\
\hline Household members & & Oil-fired central heating & 42.8 \\
\hline 1 & 12.5 & $\begin{array}{l}\text { Liquefied Petroleum Gas (LPG) } \\
\text { central heating }\end{array}$ & 1.7 \\
\hline 2 & 24.4 & $\begin{array}{l}\text { Wood-fired/pellets central } \\
\text { heating }\end{array}$ & 33.8 \\
\hline 3 & 21.5 & Wood/pellets stove & 17.7 \\
\hline 4 & 23.4 & Electric heater & 0.7 \\
\hline 5 & 10.2 & Heat accumulators & 0.3 \\
\hline More than 6 & 4.0 & Fireplace & 0.3 \\
\hline I prefer not to answer & 4.0 & Energy fireplace & 1.3 \\
\hline Coping on current income & & Other & 1.3 \\
\hline $\begin{array}{l}\text { Difficult to live on } \\
\text { current income }\end{array}$ & 9.4 & & \\
\hline Coping on current income & 53.8 & & \\
\hline $\begin{array}{l}\text { Living comfortably on } \\
\text { current income }\end{array}$ & 15.5 & & \\
\hline I prefer not to answer & 1.3 & & \\
\hline
\end{tabular}

In total, less than $10 \%$ of the households have undertaken energy efficiency improvements to their houses and about $25 \%$ of the households claim that they are planning to take energy efficiency actions in the near future. Excluding those who have already improved the energy efficiency of their homes, more than $85 \%$ of those who are not planning to invest in energy efficiency mentioned that they face financial barriers.

Concerning the energy poverty situation, approximately $30 \%$ of the households claimed that they cannot keep their house adequately warm in winter, $34 \%$ of them reported mold and damp problems and 10\% reported arrears in energy bills. However, it should be taken into account that fuels for heating purposes are always paid in cash. Based on the composite energy poverty index [43], approximately $50 \%$ of the households are at zero risk of energy poverty, $18.6 \%$ are at low risk (EP composite index $=25 \%$ ), $15.5 \%$ are at medium risk $(\mathrm{EP}$ composite index $=50 \%), 13.9 \%$ are at high risk $(\mathrm{EP}=75 \%)$ and the rest, i.e., around $3 \%$, are in excess energy poverty risk. 
Pearson's chi-square tests of independence were performed to determine whether there is a statistically significant relationship between the four subjective energy poverty indicators and the income of the households. The value of the chi-square test is calculated, as follows:

$$
\chi^{2}=\sum_{i=1}^{n} \frac{\left(O_{i}-E_{i}\right)^{2}}{E_{i}}
$$

where $\chi^{2}$ is Pearson's cumulative test statistic, which asymptotically approaches a $\chi^{2}$ distribution; $O_{i}$ is the number of observations of type $i$ (i.e., the observed frequency) and $E_{i}$ is the expected (theoretical) count of type $i$ (i.e., the expected frequency)

The chi-square test intends to determine how likely it is that an observed distribution is due to chance and the null hypothesis of the test is that no relationship exists on the categorical variables, i.e., they are independent. The null hypothesis is rejected when the $\chi^{2}$ value is large, i.e., it exceeds the $\chi^{2}$ distribution at a $5 \%$ significance level considering the degrees of the test, which are equal to the number of rows minus one times the number of columns minus one.

The null hypothesis of the chi-square test was rejected, indicating a statistically significant relationship, in the case of inability to keep the home warm during winter days $\left(\chi^{2}=15.54\right.$, d.f. $\left.=2, p=0.000\right)$, when the household has had arrears in its utility bills $\left(\chi^{2}=6.992\right.$, d.f. $\left.=2, p=0.030\right)$ and the case of the composite index $\left(\chi^{2}=21.454\right.$, d.f. $=8$, $p=0.006)$. In all these cases, the occurrence of energy vulnerability is higher in lowerincome households. The null hypothesis cannot be rejected in the case of leakages or damp walls $\left(\chi^{2}=4.188\right.$, d.f. $\left.=2, p=0.123\right)$.

\subsection{Model Estimates}

To explore the effect of energy poverty and SDCs in energy efficiency investments, five different models were run. The first model ("Basic") includes only variables related to the attributes of the experiment. The second model ("SDC") includes the attributes of the experiment, and SDCs, namely total number of household members, age class and income class. The third model ("CIEP") involves, besides the attributes of the experiment, the composite energy poverty index of Bouzarovski and Tirado Herrero [43], which is modeled as a generic attribute. The fourth model ("SIEP") examines the effect of the subjective energy poverty indicators (thermal discomfort, arrears in its utility bills and damp/mold problems) as generic attributes. The fifth and last model ("AS-SIEP") is enriched with alternative-specific subjective energy poverty indicators and aims to dissect the possible relationships between the three subjective indicators and each of the alternatives. The results of the models are presented in Table 3.

Table 3. Results of the basic, sociodemographic characteristics (SDC) and energy poverty models.

\begin{tabular}{|c|c|c|c|c|c|}
\hline Variable & Basic Model & SDC Model & CIEP Model & SIEP Model & AS-SIEP Model \\
\hline & Coeff. & Coeff. & Coeff. & Coeff. & Coeff. \\
\hline $\mathrm{ASC}_{\text {Insulation }}$ & $\begin{array}{l}1.4599^{* * *} \\
(01801)\end{array}$ & $\begin{array}{l}0.9639^{* * *} \\
(03741)\end{array}$ & $\begin{array}{l}1.6096^{* * *} \\
(01901)\end{array}$ & $\begin{array}{l}1.5727^{* * *} \\
(01906)\end{array}$ & $\begin{array}{l}1.534^{* * *} \\
(01940)\end{array}$ \\
\hline Cost $_{\text {Insulation }}$ & $\begin{array}{c}(0.1801) \\
-0.0003^{* * *} \\
(0.0000)\end{array}$ & $\begin{array}{c}(0.3741) \\
-0.0003^{* * *} \\
(0.0000)\end{array}$ & $\begin{array}{c}-0.0003^{* * *} \\
(0.0000)\end{array}$ & $\begin{array}{c}(0.1906) \\
-0.0003^{* * *} \\
(0.0000)\end{array}$ & $\begin{array}{c}(0.1940) \\
-0.0003^{* * *} \\
(0.0000)\end{array}$ \\
\hline Savings Insulation & $\begin{array}{c}0.0011^{* * *} \\
(0.0001)\end{array}$ & $\begin{array}{c}0.0011^{* * *} \\
(0.0001)\end{array}$ & $\begin{array}{c}0.0011^{* * *} \\
(0.0001)\end{array}$ & $\begin{array}{c}0.0011^{* * *} \\
(0.0001)\end{array}$ & $\begin{array}{c}0.0011^{* * *} \\
(0.0001)\end{array}$ \\
\hline ASC $_{\text {Heating }}$ & $\begin{array}{l}0.4118^{*} \\
(0.2327)\end{array}$ & $\begin{array}{l}-0.0910 \\
(0.4042)\end{array}$ & $\begin{array}{l}0.4975^{* *} \\
(0.2416)\end{array}$ & $\begin{array}{l}0.4568^{*} \\
(0.2421)\end{array}$ & $\begin{array}{l}0.5657^{* *} \\
(0.2457)\end{array}$ \\
\hline Cost $_{\text {Heating }}$ & $\begin{array}{c}-0.0013^{* * *} \\
(0.0001)\end{array}$ & $\begin{array}{c}-0.0013^{* * *} \\
(0.0001)\end{array}$ & $\begin{array}{c}-0.0013^{* * *} \\
(0.0001)\end{array}$ & $\begin{array}{c}-0.0013^{* * *} \\
(0.0001)\end{array}$ & $\begin{array}{c}-0.0013^{* * *} \\
(0.0001)\end{array}$ \\
\hline Savings Heating & $\begin{array}{c}0.0045^{* * *} \\
(0.0008)\end{array}$ & $\begin{array}{c}0.0046^{* * *} \\
(0.0008)\end{array}$ & $\begin{array}{c}0.0044^{* * *} \\
(0.0008)\end{array}$ & $\begin{array}{c}0.0044^{* * *} \\
(0.0008)\end{array}$ & $\begin{array}{c}0.0045^{* * *} \\
(0.0008)\end{array}$ \\
\hline
\end{tabular}


Table 3. Cont

\begin{tabular}{|c|c|c|c|c|c|}
\hline Variable & Basic Model & SDC Model & CIEP Model & SIEP Model & AS-SIEP Model \\
\hline & Coeff. & Coeff. & Coeff. & Coeff. & Coeff. \\
\hline \multirow[t]{2}{*}{ ASC $_{\text {Appliances }}$} & -0.0372 & -0.5483 & 0.0306 & -0.0103 & -0.0527 \\
\hline & $(0.2341)$ & $(0.4036)$ & $(0.2447)$ & $(0.2452)$ & $(0.2527)$ \\
\hline \multirow[t]{2}{*}{ Cost $_{\text {Appliances }}$} & $-0.0027^{* * *}$ & $-0.0027^{* * *}$ & $-0.0027^{* * *}$ & $-0.0027^{* * *}$ & $-0.0027^{* * *}$ \\
\hline & $(0.0003)$ & $(0.0003)$ & $(0.0003)$ & $(0.0003)$ & $(0.0003)$ \\
\hline \multirow{2}{*}{ Savings $_{\text {Appliances }}$} & $0.0115^{* * *}$ & $0.0115^{* * * *}$ & $0.0115^{* * *}$ & $0.0115^{* * *}$ & $0.0118^{* * *}$ \\
\hline & $(0.0017)$ & $(0.0018)$ & $(0.00178)$ & $(0.0018)$ & $(0.0018)$ \\
\hline HH members & - & $\begin{array}{c}0.1491^{* * *} \\
(0.0487)\end{array}$ & - & - & - \\
\hline Age class & - & $\begin{array}{c}-0.4174^{* * *} \\
(0.0632)\end{array}$ & - & - & - \\
\hline Coping on income & - & $\begin{array}{c}0.7532^{* * *} \\
(0.0997)\end{array}$ & - & - & - \\
\hline EP index & - & - & $\begin{array}{c}-0.1059^{* *} \\
(0.048)\end{array}$ & - & - \\
\hline Damp/mold & - & - & - & $\begin{array}{l}0.2258^{*} \\
(0.1319)\end{array}$ & - \\
\hline $\begin{array}{l}\text { Thermal } \\
\text { discomfort }\end{array}$ & - & - & - & $-0.5734^{* * *}$ & - \\
\hline Arrears & - & - & - & $\begin{array}{l}(0.1298) \\
0.3630^{*} \\
(0.2136)\end{array}$ & - \\
\hline Damp $/$ mold $_{\text {Insulation }}$ & - & - & - & - & $\begin{array}{c}0.5077^{* * *} \\
(0.1462)\end{array}$ \\
\hline Damp/mold ${ }_{\text {Heating }}$ & - & - & - & - & $\begin{array}{l}-0.2186 \\
(0.1769)\end{array}$ \\
\hline Damp/mold Appliances & - & - & - & - & $\begin{array}{c}0.0700 \\
(0.1819)\end{array}$ \\
\hline \multirow[t]{2}{*}{$\begin{array}{c}\text { Thermal } \\
\text { disc }_{\text {Insulation }}\end{array}$} & \multirow[t]{2}{*}{-} & \multirow[t]{2}{*}{-} & \multirow[t]{2}{*}{-} & \multirow[t]{2}{*}{-} & $-0.5358^{* * *}$ \\
\hline & & & & & $(0.1456)$ \\
\hline \multirow[t]{2}{*}{$\begin{array}{l}\text { Thermal } \\
\text { disc }_{\text {Heating }}\end{array}$} & \multirow[t]{2}{*}{-} & \multirow[t]{2}{*}{-} & - & - & $-0.6275^{* * *}$ \\
\hline & & & & & $(0.1751)$ \\
\hline $\begin{array}{c}\text { Thermal } \\
\text { disc }_{\text {Appliances }}\end{array}$ & - & - & - & - & $-0.6378^{* * *}$ \\
\hline & & & & & $(0.1855)$ \\
\hline Arrears Insulation & - & - & - & - & $\begin{array}{l}-0.3057 \\
(0.2483)\end{array}$ \\
\hline Arrears ${ }_{\text {Heating }}$ & - & - & - & - & $\begin{array}{c}0.6888^{* * *} \\
(0.2621)\end{array}$ \\
\hline Arrears Appliances & - & - & - & - & $\begin{array}{l}1.1425^{* * *} \\
(0.2570)\end{array}$ \\
\hline$-\mathrm{LL}$ & -2099.06 & -1977.50 & -2043.45 & -2034.87 & -2005.39 \\
\hline Pseudo $\mathrm{R}^{2}$ & $11.3 \%$ & $16.4 \%$ & $13.7 \%$ & $14.0 \%$ & $15.1 \%$ \\
\hline $\mathrm{n}$ & 1818 & 1788 & 1776 & 1776 & 1776 \\
\hline
\end{tabular}

Note: standard error in parentheses; ${ }^{* * *},{ }^{* * *}$ : significance at $10 \%, 5 \%$ and $1 \%$ level; -: variable is not included in the model

In all five models, the experiment attributes are statistically significant and the signs are as expected. The ASC of "heating" alternatives is statistically significant at $p=10 \%$ in the "basic" model and insignificant in the "SDC" model. In addition, the ASC of "appliances" alternatives is statistically insignificant in all model specifications. The "SDC" model presents the best fit and, further, all variables but the ASC of "heating" and "appliances" alternatives are statistically significant at $p=1 \%$ and have the expected sign. Focusing on the SDC parameters, the signs of the coefficients indicate that households with more 
members, younger householders and higher income are more likely to invest in energy efficiency. The composite energy poverty indicator ("CIEP" model) is statistically significant at $p=5 \%$. The negative sign implies that willingness to invest in energy efficiency decreases with energy poverty. According to the results of the "SIEP" model, this is attributed to the inability of households to keep their houses adequately warm. It is reminded that the weight of thermal discomfort is twice as high as that of arrears in utility bills and problems with condensation, mold or damp. Further, the thermal discomfort coefficient is statistically significant at $p=1 \%$, whereas the coefficients of the other two subjective indicators are significant at $p=10 \%$. As shown in the results of the "AS-SIEP" model, households who are unable to heat their homes adequately in winter are not willing to invest in any of the proposed alternative interventions. Those who are faced with condensation, mold or damp problems are willing to invest only in energy retrofits while those in arrears are willing to invest in upgrading their heating system and household appliances. This seemingly inconsistent behavior is explained by the association of the subjective energy poverty indicators with the household income. The percentage of low-income households among those that are faced with thermal discomfort is around $40 \%$. The respective percentage for those faced with mold and damp and arrears in energy bills is less than $25 \%$ (it is also noted that energy-bill arrears concern only $10 \%$ of the households). Household income seems to have a more significant effect on energy efficiency investments than the energy poverty indicators. To test this argument, an additional model was tested, adding energy poverty indicators in the "SDC" model (the results are omitted for conciseness reasons). Indeed, in all models, the energy poverty coefficients were statistically insignificant while household income was statistically significant at $p=1 \%$.

To facilitate the comparison across different attributes, the average marginal willingness to pay (MWTP) was calculated in Table 4 for all five models. It is mentioned that MWTP values for the subjective indicators in the "SIEP" model are calculated by the generic coefficients of the indicators divided by the respective cost coefficient of each alternative, whereas in the "AS-SIEP" model they are estimated by dividing the alternative-specific coefficients by the respective cost coefficient of each alternative.

Regarding annual savings, households on average are willing to pay around 3.4, 3.5 and 4.3 Euros for saving 1 Euro by investing in insulation, upgrading of heating systems and upgrading of household appliances, respectively. The difference in the mean WTP values, however, is not statistically significant. SDC attributes also have an impact on households' WTP values for alternative energy efficiency improvements. Specifically, WTP for energy retrofit, upgrading of heating system and upgrading of household appliances increases by about 459, 11 and 55 Euros per household member, respectively. Furthermore, an increase in age class results in a decrease of about 1285 Euros in WTP for energy retrofit. WTP for upgraded heating systems and more energy-efficient appliances also decreases by 311 and 155 Euros, accordingly. Finally, higher-income households are willing to pay more for energy efficiency improvements. According to the estimates, WTP for energy retrofit, upgraded heating systems and more energy-efficient appliances increases by 2320, 562 and 280 Euros, respectively, with an increase in income class. The differences in the WTP values for the three energy interventions are statistically significant in all SDC parameters (the null hypothesis of equal means is rejected at $p<1 \%$ in all cases).

Based on the generic coefficients (i.e., the "SIEP" model), households who face condensation, mold and damp problems are willing to pay 708.3 Euros more for energy retrofit and 178.4 Euros for upgraded heating systems compared to those who do not face similar issues (WTP for energy efficient appliances was statistically insignificant and, therefore, it is not reported). Similarly, those who are struggling to pay their energy bills are willing to pay around 1140 Euros more for energy retrofit and 140 Euros more for energy efficient appliances (WTP for upgraded heating systems is not statistically significant). Households who are unable to keep their homes warm are not willing to pay for energy interventions. The same finding is observed in the "CIEP" model regarding the composite energy poverty indicator. Finally, according to the alternative-specific energy poverty coefficients (i.e., 
the "AS-SIEP" model), those who report condensation, mold and damp problems are willing to pay only for energy retrofits (about 1650 Euros, ceteris paribus) and those who delay their bill payments are willing to upgrade their heating systems and household appliances (WTP is 539 and 422 Euros, respectively). The differences in WTP values are statistically significant in all these cases (the null hypothesis of equal means is rejected at $p<1 \%$ ).

Table 4. Marginal willingness-to-pay (MWTP) estimates for the Basic, SDC, CIEP, SIEP and AS-SIEP models.

\begin{tabular}{|c|c|c|c|c|c|}
\hline & Basic & SDC & CIEP & SIEP & AS-SIEP \\
\hline Annual savings-Insulation & 3.43 & 3.43 & 3.38 & 3.38 & 3.39 \\
\hline Annual savings-Heating & 3.43 & 3.42 & 3.47 & 3.48 & 3.50 \\
\hline Annual savings-Appliances & 4.27 & 4.26 & 4.34 & 4.34 & 4.36 \\
\hline HH members-Insulation & - & 458.94 & - & - & - \\
\hline HH members-Heating & - & 111.20 & - & - & - \\
\hline HH members-Appliances & - & 55.33 & - & - & - \\
\hline Age class-Insulation & - & -1285.11 & - & - & - \\
\hline Age class-Heating & - & -311.37 & - & - & - \\
\hline Age class-Appliances & - & -154.94 & - & - & - \\
\hline Income class-Insulation & - & 2319.28 & - & - & - \\
\hline Income class-Heating & - & 561.94 & - & - & - \\
\hline Income class-Appliances & - & 279.63 & - & - & - \\
\hline EP indicator-Insulation & - & - & -333.12 & - & - \\
\hline EP indicator-Heating & - & - & -83.75 & - & - \\
\hline EP indicator-Appliances & - & - & -39.94 & - & - \\
\hline Damp/mold-Insulation & - & - & - & 708.25 & 1560.25 \\
\hline Damp/mold-Heating & - & - & - & 178.42 & +++ \\
\hline Damp/mold-Appliances & - & - & - & +++ & +++ \\
\hline Thermal comfort-Insulation & - & - & - & -1798.53 & -1646.47 \\
\hline Thermal comfort-Heating & - & - & - & -453.07 & -491.32 \\
\hline Thermal comfort-Appliances & - & - & - & -216.02 & -235.33 \\
\hline Arrears in bills-Insulation & - & - & - & 1138.43 & +++ \\
\hline Arrears in bills-Heating & - & - & - & +++ & 539.30 \\
\hline Arrears in bills-Appliances & - & - & - & 136.74 & 421.58 \\
\hline
\end{tabular}

Note: ${ }^{+++}$: not statistically significant at $p=5 \%$; - variable is not included in the model.

In an effort to further investigate the impact of income and subjective energy poverty indicators on households' willingness to invest in energy efficiency, four additional models with split samples were run. In each model, ASCs, cost and annual savings attributes were estimated separately for each income and energy poverty class and, to interpret the findings of each model, the average MWTP per one Euro of additional annual savings was calculated per group for all alternative interventions. For conciseness reasons, the detailed model results are omitted and instead only the MWTP estimates are reported in Table 5. Further, Table 6 illustrates the estimated choice probabilities for each alternative, per model and group.

As far as the "income" model is concerned, the MWTP values suggest that households are willing to pay more for energy efficiency improvements as their income increases. For example, households who are struggling to make ends meet (i.e., those classified in Group I) are willing (or able) to invest 1.9 Euros per Euro of annual savings, which is almost half of the households who are coping on current income and about one-third of the households who are living comfortably. The differences in the MWTP values for the same alternatives across income groups as well as the MWTP values of different alternatives in the same income group are statistically significant (the null hypothesis of equal means is rejected at $p<1 \%$ in all cases). The influence of income is also reflected in households' choices. The "opt-out" alternative is selected by 34\% of Group I participants, 19\% of Group II participants and only $8.5 \%$ of Group III participants. 
Table 5. MWTP estimates for the split models per group.

\begin{tabular}{|c|c|c|c|c|}
\hline Alternative & Income Model & Mold/Damp Model & Thermal Discomfort Model & Arrears in Bills Model \\
\hline \multicolumn{5}{|c|}{ Group I } \\
\hline Annual savings-Insulation & 1.87 & 3.78 & 3.84 & 3.55 \\
\hline Annual savings-Heating & 3.72 & 2.94 & 3.73 & 3.40 \\
\hline Annual savings-Appliances & 3.38 & 4.45 & 4.27 & 4.60 \\
\hline \multicolumn{5}{|c|}{ Group II } \\
\hline Annual savings-Insulation & 3.35 & 2.95 & 2.24 & +++ \\
\hline Annual savings-Heating & 4.23 & 4.97 & 2.84 & +++ \\
\hline Annual savings-Appliances & 4.02 & 4.10 & 4.26 & +++ \\
\hline \multicolumn{5}{|c|}{ Group III } \\
\hline Annual savings-Insulation & 5.51 & & & \\
\hline Annual savings-Heating & +++ & & & \\
\hline Annual savings-Appliances & +++ & & & \\
\hline
\end{tabular}

Note: ${ }^{+++}$: not statistically significant at $p=5 \%$; - variable is not included in the model; Income-Group I: Difficult to live on current income, Group II: Coping on current income, Group III: Living comfortably on current income; Damp/mold problems-Group I: No condensation, mold and damp issues, Group II: Condensation, mold and damp issues; Inability to keep house warm-Group I: Ability to keep house adequately warm, Group II: Inability to keep house adequately warm; Arrears in energy bills—Group I: No arrears in energy bills, Group II: Arrears in energy bills.

Table 6. Choice probabilities for each alternative per model and group.

\begin{tabular}{|c|c|c|c|c|}
\hline Alternative & Income Model & Mold/Damp Model & Thermal Discomfort Model & Arrears in Bills Model \\
\hline \multicolumn{5}{|c|}{ Group I } \\
\hline House insulation & $36.1 \%$ & $40.5 \%$ & $43.9 \%$ & $45.0 \%$ \\
\hline Heating system & $19.3 \%$ & $21.8 \%$ & $20.8 \%$ & $19.0 \%$ \\
\hline Household appliances & $10.9 \%$ & $15.6 \%$ & $16.6 \%$ & $14.0 \%$ \\
\hline No option & $33.7 \%$ & $22.1 \%$ & $18.7 \%$ & $22.0 \%$ \\
\hline \multicolumn{5}{|c|}{ Group II } \\
\hline House insulation & $44.0 \%$ & $48.9 \%$ & $41.1 \%$ & $30.0 \%$ \\
\hline Heating system & $19.6 \%$ & $14.9 \%$ & $16.7 \%$ & $24.0 \%$ \\
\hline Household appliances & $17.6 \%$ & $15.5 \%$ & $13.8 \%$ & $28.3 \%$ \\
\hline No option & $18.8 \%$ & $20.7 \%$ & $28.4 \%$ & $17.7 \%$ \\
\hline \multicolumn{5}{|c|}{ Group III } \\
\hline House insulation & $52.8 \%$ & - & - & - \\
\hline Heating system & $20.2 \%$ & - & - & - \\
\hline Household appliances & $18.5 \%$ & - & - & - \\
\hline No option & $8.5 \%$ & - & - & - \\
\hline
\end{tabular}

Note: -: Only two groups exist for these models; Income-Group I: Difficult to live on current income, Group II: Coping on current income, Group III: Living comfortably on current income; Damp/mold problems-Group I: No condensation, mold and damp issues, Group II: Condensation, mold and damp issues; Inability to keep house warm-Group I: Ability to keep house adequately warm, Group II: Inability to keep house adequately warm; Arrears in energy bills—Group I: No arrears in energy bills, Group II: Arrears in energy bills.

Households facing condensation, mold and damp problems are willing to pay 5 Euros more per one Euro of annual savings for upgrading their heating system. Energy retrofit has the lowest MWTP (almost 3 Euros per one Euro of annual savings), whereas upgrading of household appliances lies in the middle (around 4 Euros per one Euro of annual savings). On the other hand, those who are not facing these issues are willing to pay around 4.5 Euros for a more energy-efficient appliance, 3.8 Euros for energy retrofits and 2.9 Euros for more efficient heating systems per one Euro of annual savings. Again, the differences in the mean MWTP values for the three alternatives are statistically significant at $p=5 \%$ between and across the two groups. Investing in energy retrofit is the most preferred choice, especially for those who suffer from condensation, mold and damp problems. Another interesting point is that the "opt-out" alternative is more preferable than the "appliances" alternative, coinciding with the negative sign in the ASC of the "appliances" alternative in almost 
all the models tested (it is reminded, however, that the coefficient was not statistically significant at $p=10 \%$ ).

Households who report that they are unable to stay comfortably warm are willing to pay 4.3 Euros for more energy-efficient appliances, 2.8 Euros for more efficient heating systems and 2.2 Euros for energy retrofits per one Euro of annual savings. MWTP for more energy-efficient appliances is practically the same for those who do not experience thermal discomfort in their homes. MWTP for more efficient heating systems and energy retrofits increases to 3.7 Euros and 3.8 Euros, respectively, per one Euro of annual savings. The null hypothesis about the equality of means is rejected at $p=1 \%$ for the MWTP values of the alternative interventions between and across the two groups. Energy retrofit is once more the most preferred alternative and the "opt-out" option is more preferable to the "appliances" option. It is also worth noting that the probability of choosing the "optout" alternative increases by $10 \%$ in the "discomfort" group (i.e., Group II). As explained earlier, this finding is related to the lower-income class of those who are faced with thermal discomfort and is supported also by the findings of the "income" model.

MWTP values for those who report arrears in energy payments are not provided because they are statistically insignificant. Regarding Group I (i.e., those who do not report arrears in energy bills), the estimated MWTP values for energy retrofits, upgrading of heating systems and upgrading of household appliances are 3.6, 3.4 and 4.6 Euros respectively, for every Euro saved per year. The preference probabilities show a similar pattern with that of the other two subjective indicators models, i.e., the "insulation" alternative is the most preferred choice and the "opt-out" alternative is more preferable than the "appliances" choice. It is interesting, however, that those who report arrears in bills tend to have higher preferences for the "heating" and "appliances" alternatives compared to those who are unable to stay comfortably warm or face damp problems.

\section{Discussion and Conclusions}

There is no doubt that energy poverty is foremost a political problem, triggered, especially in prosperous economies, by social inequality. In this regard, boosting the income of vulnerable households is the most preferred and effective option to address energy poverty. This would allow households in need not only to gain access to vital energy services but also to promote investments in energy efficiency (e.g., energy retrofits, replacement of old household appliances, upgrading of inefficient heating systems etc.) that would create long-term benefits for society and the environment. So far, policy-making is fed by assessments that are typically conducted at a national scale. This involves some degree of data flattening that may hinder the opportunity for more effective energy poverty alleviation measures [49].

Focusing on energy efficiency as a case study, a measure typically incorporated in National Energy and Climate Plans (NECPs) to address energy poverty, this paper aims to shed light on the need to gradually move toward more locally targeted-not to say personalized-actions like scholars in the field suggest $[49,50]$. In this direction, the connection between energy poverty and energy efficiency investment decisions is investigated using a stated choice experiment and, to the authors' best knowledge, it is the first study in this field.

From a policy perspective, it is important to underline, first, the differences in the preferences of vulnerable households depending on the different aspects of energy poverty. For instance, those who are unable to keep a level of thermal comfort at home are less willing to invest in energy efficiency, per se, contrary to those who are faced with damp problems or arrears in bills. The main reason behind this seemingly unexpected behavior is that a significant percentage of those households, at least in our sample, belonged to the lower-income group. Vulnerable households also hold different WTP values for each of the proposed interventions. Most importantly, these differences are not observed only across groups but also between groups. For example, those who claim inability to keep their houses adequately warm are willing to pay around 2.8 Euros for every 
Euro saved on an annual basis from the upgrading of the heating system, whereas those who face damp problems are willing to pay around 5 Euros, respectively. In general, energy retrofit measures are the most preferred alternative, regardless of other factors. This may be related to unobserved benefits of retrofits, e.g., insulation may enhance occupant's comfort and increase the future resale value [51]. According to the findings of the study, the energy poverty alleviation policies in Greece and elsewhere should target the underlying causes of both energy poverty and the energy-efficiency paradox, which in this case is related to vulnerable households who may be dropped out of subsidy schemes. Recent studies show that the implementation of government-funded assistance programs is less successful than expected due to institutional and bureaucratic barriers (e.g., funding instability, limited advertising funding and cumbersome paperwork) [52]. To increase the participation of low-income households in the adoption of energy technologies, innovative approaches, such as community-based energy programmes are required [53]. In this direction, central governments should offer local authorities greater flexibility concerning funding and eligibility criteria and should collaborate with utilities and local charity organizations to identify energy-poor consumer groups [52]. In addition, moving from national to local scale would allow for capturing energy vulnerable households that are "invisible" to national policies. Local actions involving cross-sectional studies, smart metering and citizen science and crowdsourcing could be helpful towards making a transition from "object-oriented strategies" that target the built environment to "subjectoriented strategies", which offer support to households [49]. For example, appropriately designed information campaigns could help vulnerable consumers to better understand the tradeoffs between initial investments and future energy savings, or be informed about available support schemes that fit their needs. Furthermore, diversified policies could be adopted to narrow the gap for those who give different importance to the alternative energy-efficiency measures as a result of the different aspects of energy poverty.

Sociodemographic characteristics of the respondents, which are known to be related to energy poverty, such as income and age, also possess a crucial role in the energy efficiency decision-making process. In general, elderly people, who are more prone to energy poverty, are at the same time more reluctant to invest in energy saving. The same conclusion is drawn for low-income households. Further, the estimated values show that households who are struggling to live on their income can afford to pay for energy retrofits only onethird of the amount estimated for households who are living comfortably. These findings are worrisome because without support to implement structural measures like energy efficiency, elderly and low-income households could be trapped in the vicious circle of energy poverty, as previous studies suggest, e.g., [54-56].

Finally, it seems that vulnerable households are more prone to the so-called "discounting gap", i.e., the gap between the market discount rates and the subjective discount rates (also known as implicit discount rates-IDR) employed by consumers when discounting future savings, which is closely related to the "energy efficiency gap" [57]. Assuming typical lifetimes of 25 years for insulation, 15 years for heating systems and 12 years for household appliances, the IDRs were estimated per group and alternative. IDRs vary between $20 \%$ and 50\%. Coinciding with previous research, e.g., [30,58-61], low-income households seem to use a higher discount rate compared with wealthier ones, which means that they favor the short-term over long-term outcomes and, thus, are more likely to make myopic decisions. For instance, the estimated IDR for insulation was $45 \%$ for households who are unable to keep their houses adequately warm and $26 \%$ for those who do not face a similar situation. As a result, vulnerable consumers are less likely to escape energy poverty because they fail to engage in actions that benefit them in the long term $[30,61]$.

These findings should be seen as a first attempt to explore the role of energy poverty on energy efficiency decisions and leave space for future research. Further, it should be noted that, like any other stated preference survey, the reliability of the outcomes is strongly affected by participants' ability to provide honest and careful answers to the survey questions. Future surveys should extend the research field by also investigating the role of other 
factors that are known to influence energy efficiency decisions, i.e., market and behavioral biases. For instance, increasing energy efficiency is closely related to the development of renewable energy sources and the reduction of emissions [62]. Similarly, investments in renewable energy (e.g., photovoltaics and wind farms) and the role of the active consumer (i.e., prosumer), which will enable a transition from the traditional centralized power network to decentralized smart grids, should be investigated [63,64]. In addition, since energy poverty is a multidimensional problem, including diverse metrics at different geographical scales would be valuable for testing vulnerable households' decisions. Further, future choice experiments could be designed to test participants' preferences, whilst controlling for the effect of savings and upfront costs more effectively. For example, split-sample designs could be used to control for the impact of the lifetime of the investment or the format of the savings (e.g., annual savings vs. lifetime savings). In this way, it could be possible to estimate the participants' IDR in relation to their income and energy vulnerability. In addition, provided that previous research in the field of behavioral economics suggests that, due to loss aversion, decisions are affected by whether an option is presented as a gain or as a loss [65], split-sample approaches could be implemented (e.g., annual savings vs. annual additional costs) to investigate the format and the effectiveness of the monetary information.

Author Contributions: Conceptualization, D.D. and C.K.; data curation, A.B.; formal analysis, D.D.; methodology, D.D., C.K., A.B. and L.P.; project administration, D.D.; writing一original draft, D.D. and C.K.; writing-review and editing, L.P. All authors have read and agreed to the published version of the manuscript. The manuscript solely reflects authors' views.

Funding: This work was supported by the STEP-IN Project (Using Living Labs to roll out Sustainable Strategies for Energy Poor Individuals) funded from the European Union's Horizon 2020 research and innovation programme (Contract No. 785125).

Institutional Review Board Statement: The study was conducted according to the General Data Protection Regulation (Regulation No. 2016/679) and approved by the Research Ethics Committee of the National Technical University of Athens (on 18 April 2019).

Informed Consent Statement: Informed consent was obtained from all subjects involved in the study.

Data Availability Statement: Data are not publicly available due to the privacy of respondents.

Conflicts of Interest: The authors declare that they have no conflict of interest.

\section{References}

1. Bouzarovski, S.; Thomson, H.; Cornelis, M.; Varo, A.; Guyet, R. Towards an Inclusive Energy Transition in the European Union: Confronting Energy Poverty Amidst a Global Crisis; European Commission: Luxembourg, 2020. [CrossRef]

2. Thomson, H.; Snell, C.; Bouzarovski, S. Health, Well-Being and Energy Poverty in Europe: A Comparative Study of 32 European Countries. Int. J. Environ. Res. Public Health 2017, 14, 584. [CrossRef]

3. Oliveras, L.; Peralta, A.; Palència, L.; Gotsens, M.; López, M.J.; Artazcoz, L.; Borrell, C.; Marí-Dell'Olmo, M. Energy poverty and health: Trends in the European Union before and during the economic crisis, 2007-2016. Health Place 2021, 67, 102294. [CrossRef]

4. Papada, L.; Katsoulakos, N.; Doulos, I.; Kaliampakos, D.; Damigos, D. Analyzing energy poverty with Fuzzy Cognitive Maps: A step-forward towards a more holistic approach. Energy Sources Part B Econ. Plan. Policy 2019, 14, 159-182. [CrossRef]

5. Bollino, C.; Botti, F. Energy Poverty in Europe: A Multidimensional Approach. PSL Q. Rev. 2017, 70, 473-507. [CrossRef]

6. Thomson, H.; Snell, C. Quantifying the prevalence of fuel poverty across the European Union. Energy Policy $2013,52,563-572$. [CrossRef]

7. Robinson, C.; Bouzarovski, S.; Lindley, S. 'Getting the measure of fuel poverty': The geography of fuel poverty indicators in England. Energy Res. Soc. Sci. 2018, 36, 79-93. [CrossRef]

8. Papada, L.; Kaliampakos, D. A Stochastic Model for energy poverty analysis. Energy Policy 2018, 116, 153-164. [CrossRef]

9. Robinson, C.; Bouzarovski, S.; Lindley, S. Underrepresenting neighbourhood vulnerabilities? The measurement of fuel poverty in England. Environ. Plan. A Econ. Space 2018, 50, 1109-1127. [CrossRef]

10. Bouzarovski, S. Energy poverty in the European Union: landscapes of vulnerability. Wiley Interdiscip. Rev. Energy Environ. 2013, 3, 276-289. [CrossRef]

11. O'Sullivan, K.; Barnard, L.T.; Viggers, H.; Howden-Chapman, P. Child and youth fuel poverty: assessing the known and unknown. People Place Policy Online 2016, 10, 77-87. [CrossRef] 
12. Gillard, R.; Snell, C.; Bevan, M. Advancing an energy justice perspective of fuel poverty: Household vulnerability and domestic retrofit policy in the United Kingdom. Energy Res. Soc. Sci. 2017, 29, 53-61. [CrossRef]

13. Kyprianou, I.; Serghides, D.; Varo, A.; Gouveia, J.; Kopeva, D.; Murauskaite, L. Energy poverty policies and measures in 5 EU countries: A comparative study. Energy Build. 2019, 196, 46-60. [CrossRef]

14. Pye, S.; Dobbins, A.; Baffert, C.; Brajković, J.; Deane, P.; De Miglio, R. Energy Poverty Across the EU. Eur. Energy Transit. Insights Policy Mak. 2017, 261-280. [CrossRef]

15. Rivas, S.; Cuniberti, B.; Bertoldi, P. Information Measures to Promote Energy Use Reduction across EU Member States; European Union: Luxembourg, 2016. [CrossRef]

16. European Energy Network. EnR Position Paper on Energy Poverty in the European Union 2019. Available online: https: / / enr-network.org/wp-content/uploads/ENERGYPOVERTY-EnRPositionPaper-Energypoverty-Jan-2019.pdf (accessed on 12 February 2021).

17. Aydin, E.; Brounen, D.; Kok, N. Information provision and energy consumption: Evidence from a field experiment. Energy Econ. 2018, 71, 403-410. [CrossRef]

18. Lakatos, E.; Arsenopoulos, A. Investigating EU financial instruments to tackle energy poverty in households: A SWOT analysis. Energy Sources Part B Econ. Plan. Policy 2019, 14, 235-253. [CrossRef]

19. Jaffe, A.B.; Stavins, R.N. The energy-efficiency gap What does it mean? Energy Policy 1994, 22, 804-810. [CrossRef]

20. Gerarden, T.D.; Newell, R.G.; Stavins, R.N. Assessing the Energy-Efficiency Gap. J. Econ. Lit. 2017, 55, 1486-1525. [CrossRef]

21. Abrardi, L. Behavioral barriers and the energy efficiency gap: a survey of the literature. Econ. Political Ind. 2018, 46, 25-43. [CrossRef]

22. Allcott, H. Consumers' Perceptions and Misperceptions of Energy Costs. Am. Econ. Rev. 2011, 101, 98-104. [CrossRef]

23. Allcott, H. Paternalism and Energy Efficiency: An Overview. Annu. Rev. Econ. 2016, 8, 145-176. [CrossRef]

24. Allcott, H.; Greenstone, M. Is There an Energy Efficiency Gap? Energy Effic. 2013, 133-161. [CrossRef]

25. Gillingham, K.; Palmer, K. Bridging the Energy Efficiency Gap: Policy Insights from Economic Theory and Empirical Evidence. Rev. Environ. Econ. Policy 2014, 8, 18-38. [CrossRef]

26. Poortinga, W.; Steg, L.; Vlek, C.; Wiersma, G. Household preferences for energy-saving measures: A conjoint analysis. J. Econ. Psychol. 2003, 24, 49-64. [CrossRef]

27. Newell, R.G.; Siikamäki, J. Individual Time Preferences and Energy Efficiency. Am. Econ. Rev. 2015, 105, 196-200. [CrossRef]

28. Newell, R.G.; Siikamäki, J. Nudging Energy Efficiency Behavior: The Role of Information Labels. J. Assoc. Environ. Resour. Econ. 2014, 1, 555-598. [CrossRef]

29. Brent, D.A.; Ward, M.B. Energy efficiency and financial literacy. J. Environ. Econ. Manag. 2018, 90, 181-216. [CrossRef]

30. Dellavalle, N. People's decisions matter: understanding and addressing energy poverty with behavioral economics. Energy Build. 2019, 204, 109515. [CrossRef]

31. Adamkovič, M.; Martončik, M. A Review of Consequences of Poverty on Economic Decision-Making: A Hypothesized Model of a Cognitive Mechanism. Front. Psychol. 2017, 8, 1784. [CrossRef]

32. Shah, A.K.; Mullainathan, S.; Shafir, E. Some Consequences of Having Too Little. Science 2012, 338, 682-685. [CrossRef] [PubMed]

33. Carvalho, L.S.; Meier, S.; Wang, S.W. Poverty and Economic Decision-Making: Evidence from Changes in Financial Resources at Payday. Am. Econ. Rev. 2016, 106, 260-284. [CrossRef]

34. French, D.; McKillop, D. Financial literacy and over-indebtedness in low-income households. Int. Rev. Financ. Anal. 2016, 48, 1-11. [CrossRef]

35. Liu, L.; Feng, T.; Suo, T.; Lee, K.; Li, H. Adapting to the Destitute Situations: Poverty Cues Lead to Short-Term Choice. PLoS ONE 2012, 7, e33950. [CrossRef]

36. Simonovic, B.; Stupple, E.J.N.; Gale, M.; Sheffield, D. Stress and Risky Decision Making: Cognitive Reflection, Emotional Learning or Both. J. Behav. Decis. Mak. 2017, 30, 658-665. [CrossRef]

37. Heilman, R.M.; Crişan, L.G.; Houser, D.; Miclea, M.; Miu, A.C. Emotion regulation and decision making under risk and uncertainty. Emotion 2010, 10, 257-265. [CrossRef]

38. Dellavalle, N.; Bisello, A.; Balest, J. In search of behavioural and social levers for effective social housing retrofit programs. Energy Build. 2018, 172, 517-524. [CrossRef]

39. Santangelo, A.; Tondelli, S. Occupant behaviour and building renovation of the social housing stock: Current and future challenges. Energy Build. 2017, 145, 276-283. [CrossRef]

40. Kearns, A.; Whitley, E.; Curl, A. Occupant behaviour as a fourth driver of fuel poverty (aka warmth \& energy deprivation). Energy Policy 2019, 129, 1143-1155. [CrossRef]

41. Hensher, D.A.; Rose, J.M.; Greene, W.H. Applied Choice Analysis. RePEc 2005. [CrossRef]

42. Street, D.J.; Burgess, L.; Viney, R.; Louviere, J. Designing Discrete Choice Experiments for Health Care. Benefit Transf. Environ. Resour. Values 2008, 11, 47-72. [CrossRef]

43. Bouzarovski, S.; Herrero, S.T. The energy divide: Integrating energy transitions, regional inequalities and poverty trends in the European Union. Eur. Urban Reg. Stud. 2017, 24, 69-86. [CrossRef] [PubMed]

44. Lancaster, K.T. A New Approach to Consumer Theory. J. Political Econ. 1966, 74, 132-157. [CrossRef]

45. Hausman, J.; McFadden, D. Specification Tests for the Multinomial Logit Model. Econometrica 1984, 52, 1219. [CrossRef]

46. Krinsky, I.; Robb, A.L. On Approximating the Statistical Properties of Elasticities. Rev. Econ. Stat. 1986, 68, 715. [CrossRef] 
47. Greene, W.H. NLOGIT Version 6-Reference Guide; Econometric Software Inc.: Plainview, NY, USA, 2016.

48. Holmes, T.P.; Adamowicz, W.L.; Carlsson, F. Choice Experiments. Environ. Value Transf. Issues Methods 2017, 13, 133-186.

49. Sareen, S.; Thomson, H.; Herrero, S.T.; Gouveia, J.P.; Lippert, I.; Lis, A. European energy poverty metrics: Scales, prospects and limits. Glob. Transit. 2020, 2, 26-36. [CrossRef]

50. Bouzarovski, S.; Simcock, N. Spatializing energy justice. Energy Policy 2017, 107, 640-648. [CrossRef]

51. Hyland, M.; Lyons, R.C.; Lyons, S. The value of domestic building energy efficiency-Evidence from Ireland. Energy Econ. 2013, 40, 943-952. [CrossRef]

52. Raissi, S.; Reames, T.G. "If we had a little more flexibility." perceptions of programmatic challenges and opportunities implementing government-funded low-income energy efficiency programs. Energy Policy 2020, 147, 111880. [CrossRef]

53. Reames, T.G. A community-based approach to low-income residential energy efficiency participation barriers. Local Environ. 2016, 21, 1449-1466. [CrossRef]

54. González-Eguino, M. Energy poverty: An overview. Renew. Sustain. Energy Rev. 2015, 47, 377-385. [CrossRef]

55. Santamouris, M.; Alevizos, S.; Aslanoglou, L.; Mantzios, D.; Milonas, P.; Sarelli, I.; Karatasou, S.; Cartalis, K.; Paravantis, J. Freezing the poor-Indoor environmental quality in low and very low income households during the winter period in Athens. Energy Build. 2014, 70, 61-70. [CrossRef]

56. Terés-Zubiaga, J.; Martín, K.; Erkoreka, A.; Sala, J.; Escudero, K.M. Field assessment of thermal behaviour of social housing apartments in Bilbao, Northern Spain. Energy Build. 2013, 67, 118-135. [CrossRef]

57. Stadelmann, M. Mind the gap? Critically reviewing the energy efficiency gap with empirical evidence. Energy Res. Soc. Sci. 2017, 27, 117-128. [CrossRef]

58. Dubin, J.A.; McFadden, D.L. An Econometric Analysis of Residential Electric Appliance Holdings and Consumption. Econometrica 1984, 52, 345. [CrossRef]

59. Gabaix, X.; Laibson, D. Myopia and Discounting. Myopia Discount. 2017. [CrossRef]

60. Hausman, J.A. Individual Discount Rates and the Purchase and Utilization of Energy-Using Durables. Bell J. Econ. 1979, 10. [CrossRef]

61. Jachimowicz, J.M.; Chafik, S.; Munrat, S.; Prabhu, J.C.; Weber, E.U. Community trust reduces myopic decisions of low-income individuals. Proc. Natl. Acad. Sci. USA 2017, 114, 5401-5406. [CrossRef] [PubMed]

62. Borowski, P. Innovative Processes in Managing an Enterprise from the Energy and Food Sector in the Era of Industry 4.0. Processes 2021, 9, 381. [CrossRef]

63. Borowski, P.F. Zonal and Nodal Models of Energy Market in European Union. Energies 2020, 13, 4182. [CrossRef]

64. Leal-Arcas, R.; Lesniewska, F.; Proedrou, F. Prosumers as New Energy Actors. In Africa-EU Renewable Energy Research and Innovation Symposium 2018 (RERIS 2018). RERIS, 2018; Mpholo, M., Steuerwald, D., Kukeera, T., Eds.; Springer: Cham, Switzerland, 2018. [CrossRef]

65. Tversky, A.; Kahneman, D. The framing of decisions and the psychology of choice. Science 1981, 211, 453-458. [CrossRef] [PubMed] 